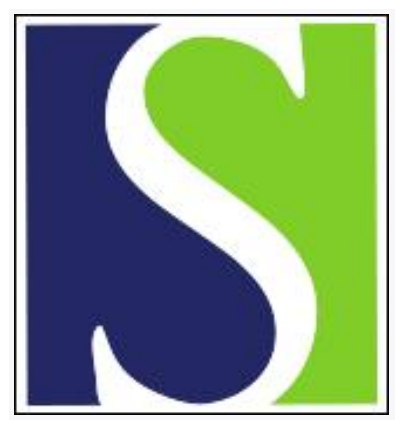

Scand J Work Environ Health 2009;35(6):413-420

https://doi.org/10.5271/sjweh.1361

Published online: 05 Oct 2009, Issue date: 00 Dec 2009

The Occupational Safety and Health Scorecard - a business case example for strategic management

by Köper B, Möller K, Zwetsloot G

Affiliation: Bundesanstalt für Arbeitsschutz und Arbeitsmedizin, D-44149 Dortmund, Germany. koeper.birgit@baua.bund.de

Refers to the following text of the Journal: 2009;35(6):403-413

The following articles refer to this text: 2010;36(4):313-318;

2010;36(4):269-271; 2021;47(4):318-327

Key terms: Balanced Scorecard; business case; business performance; case study; cause and effect chain; constructive research approach; empirical study; human resource management; management control; occupational safety and health; Occupational Safety and Health Scorecard; organizational performance; performance indicator; strategic management

This article in PubMed: www.ncbi.nlm.nih.gov/pubmed/19806280 


\title{
The occupational safety and health scorecard - a business case example for strategic management
}

\author{
by Birgit Köper, PhD, ${ }^{1}$ Klaus Möller, PhD, ${ }^{2}$ Gerard Zwetsloot, PhD ${ }^{3}$
}

Köper B, Möller K, Zwetsloot G. The Occupational Safety and Health Scorecard - a business case example for strategic management. Scand J Work Environ Health. 2009;35(6):413-420.

Objective Human resources and health issues are crucial in terms of corporate competitiveness. However, systematic, continuous and strategically aligned occupational safety and health (OSH) management is scarcely applied in companies. One major reason for this could be the lack of generally accepted and standardised OSH control methods. Our objective was thus to conceptualize a method by which qualitative factors such as human resources and $\mathrm{OSH}$ aspects contribute to the performance or value-added layer of an organization.

Methods We developed a business case based on the well-known and accepted Balanced Scorecard approach, which we adapted and applied to the management of OSH issues. The concept was implemented in the course of a comprehensive case study at a German automobile manufacturer. We gathered health as well as finance data in order to test which health-related indicators had an impact on financial performance. The demonstration of, and reporting on, how the promotion of workplace health contributes strategically to the organization is crucial for both health and human resource managers.

Results Based on multivariate regression analyses, our main finding was that the Balanced Scorecard approach is an adequate means to control OSH issues in terms of strategic health management. Our analyses demonstrated that health-related interventions contribute significantly to performance aspects such as quality, productivity, absenteeism, and cost reduction. Therefore, the financial impact of health-related aspects / interventions could be demonstrated by means of the OSH scorecard.

Conclusions The availability and quality of health data within the context of overall corporate performance data needs to be improved in order to bridge the OSH-related and performance issues of an organization.

Key terms Balanced Scorecard; business performance; case study; cause and effect chain; constructive research approach; empirical study; human resource management; management control; organizational performance; performance indicator.

Many European countries have developed from industryto service- or knowledge-based economies during the last decades. Globalization, increased pressure to innovate, and growing competition for talented workers have incentivized organizations to review their employee-relation strategies in order to attract, motivate, and retain a qualified workforce that will help them to be successful (1). Investments in occupational safety and health (OSH) as part of human resource management ${ }^{4}$ have, therefore, potentially a value for business and should be crucial to future competitiveness. This value can be measured and reported to management by means of practical business cases. The fundamental idea behind applying business cases to human resources (including OSH) is that it is both possible and necessary to organize work in accordance with accepted working conditions and long-term economic efficiency. Hence positive associations between human-related resources and organizational performance are presumed (2). Already in the 1960s, first attempts were made to account for the human factor (3).

1 Bundesanstalt für Arbeitsschutz und Arbeitsmedizin, Dortmund, Germany.

2 Georg-August-University Göttingen, Göttingen, Germany.

3 TNO Quality of Life - Work and Employment, Hoofddorp, the Netherlands.

4 Most studies refer to human capital or human resource management rather than to OSH exclusively. We regard OSH as an important part of human resources. The relevant terms human capital, human resources and OSH are defined within the theory chapter.

Correspondence to: Dr B Köper, Bundesanstalt für Arbeitsschutz und Arbeitsmedizin, Friedrich-Henkel-Weg 1-25, D-44149 Dortmund, Germany. [E-mail: koeper.birgit@baua.bund.de] 
In this article, we tackle the business perspective on OSH and address the questions and problems faced by corporate management when assessing the availability and applicability of effective control systems to manage health and safety issues (and human resources more broadly) and show their contribution to organizational performance and competitiveness. Thus our major objective was to link OSH - as part of human resources - to overall organizational business issues through the use of a case study. In doing so, we demonstrated the feasibility of applying the Balanced Scorecard approach to strategic OSH management $(4,5)$. As a first step, we describe the underlying theoretical assumptions connecting human resources and OSH issues to corporate performance and highlight that there is still a lack of generally accepted theory-based models in this field.

\section{Theory}

In building a bridge between human resource/OSH issues and the organization's performance, we define some essential terms such as "business case", "human capital", "human resources", and "health":

The business case for OSH is defined as the (potential) value of $\mathrm{OSH}$ as seen from a business perspective. The objective of the business case is hence to obtain management commitment and approval for investment in health and safety by means of transparent arguments and increase the use of OSH interventions in companies. The business case is supposed to demonstrate that $\mathrm{OSH}$ investments have effects on both the organizational (eg, productivity, quality, cost reduction) and individual level (eg, engagement, motivation, job satisfaction) $(6,7)$. Thus, the OSH business case plays an important role in reporting the contribution of OSH to the organization's strategic objectives.
Human capital refers to the benefits gained from investments in knowledge, skills, and qualifications of people by means of education and individual development programs, respecting individual characteristics, attitudes, and motivation $(2,8-10)$. In this article, the following definition is used: "The human capital of an organisation represents the entire (physical, mental, and social) individual and collective performance potentials of its employees" (9, p 16).

Human resources, in contrast, are particular aspects of the individual and social performance potentials, such as physical and psychological health, knowledge, skills, motivation, trust, social support, and cooperation. This definition follows the commonly applied subordination of the term human resources to the broader meaning of human capital. Hence, the definition includes not only the actual utilization of employees' skills (for example, in the process of organizational performance), but also their potential usefulness (9).

The World Health Organisation defines health as a complete state of physical, mental, and social wellbeing, not merely the absence of disease or infirmity (11). Health also comprises aspects of work ability and selfmanagement $(4,12)$. We, therefore, regard health as part of human resources, and the promotion of health as an aspect of human resource management.

The likely relationship between human resource issues and organizational performance are illustrated by Becker et al (2) in figure 1.

These definitions already point to the complexity of the relations which have to be measured and set out in business cases. Organizations are complex socioeconomic systems, which must adapt to (enormous) external and internal changes (13). These complex socio-technical systems cannot be understood by merely analyzing their single components or their individual relationships. In addition to the fact that the reduction of a complex system to single causal relationships does
1

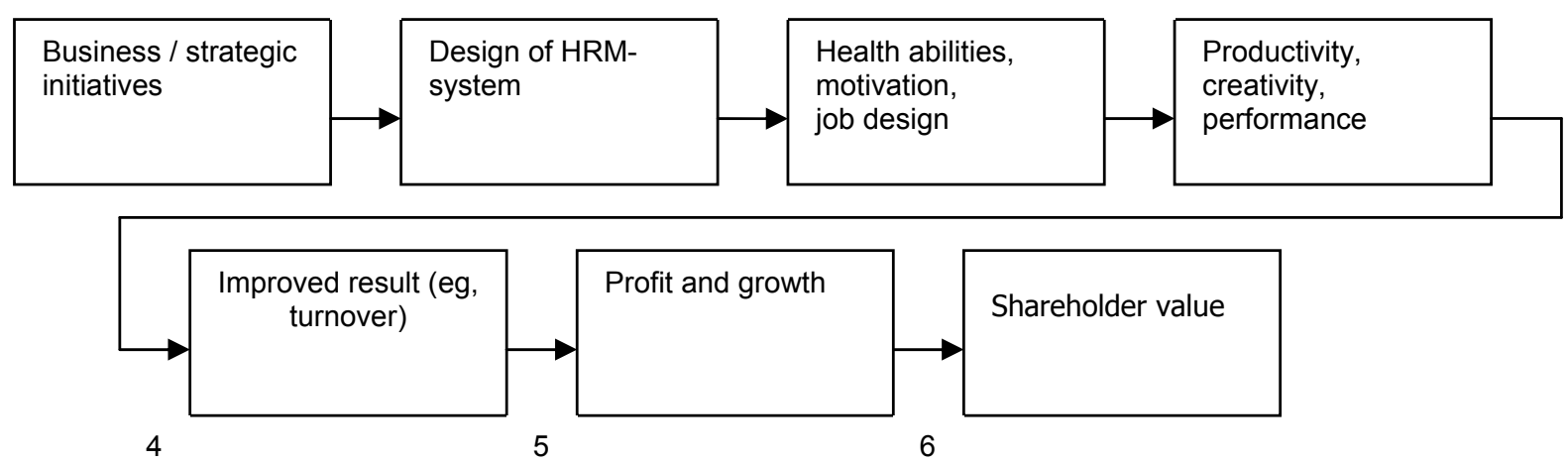

Figure 1. Heuristic chain / relation of human resources and shareholder value (modified from reference 2). (HRM=human resource management) 
not represent the corporate reality, the relation of human resource/OSH investments to financial outcomes is quite complex. Results of empirical analyses based on simplified models are, therefore, not fully adaptable to the detailed cause and effect chains in complex systems.

To date, neither binding standards nor regulations exist for internal or external reporting of human capital or respectively $\mathrm{OSH}$ in organizations. There are certainly interesting examples [eg, the Finnish experience with work ability and human resource reporting (14), the Swedish experience with a health statement (15)], but they hardly play a role in the shareholder value perspective and the communication of capital markets (16). One reason for this might be the lack of broadly accepted theory approaches and models. The most cited of these approaches are roughly presented in table 1 .

There are many studies that focus on investment in human capital/human resources and financial success; they often fall in the category of "best employer studies" $(9,23)$. Such studies take a resource-based view of a firm as their theoretical background. Dating back to the $1950 \mathrm{~s}$, the resource-based view is still the most-cited theory background in the field of best employer studies. With reference to the heuristic chain from human resource strategy to shareholder value, the resource-based view focuses on the creation of the organization's specific resources (see step 2 in figure 1). In contrast, the arguments of strategic human resource management concentrate on the strategy as the fundamental building block of all activities in the field of human resources. Advocates of this approach (see table 1) claim that human resource interventions contribute to organizational performance if they are aligned to the overall corporate strategy.

Signaling and the social identity theories focus on an internal stakeholder group (as opposed to the shareholder perspective) and claim that staff members or potential job applicants assess the attractiveness of an organization based on its human resource/OSH initiatives. Since it is important for organizational performance to attract qualified people, these theories contribute to the overall theory discussion.

However all these approaches - each tackling one specific perspective - are not yet combined in terms of a standard theory. Moreover, despite being the mostcited theory, the resource-based view has also been criticized: Glaser et al (9) state that this theory does not take into account the effects of health-related factors (such as engagement, motivation, and job satisfaction, amongst others) on specific performance indicators (eg, productivity, quality, cost reduction). To date, the impact of human-related aspects on performance indicators have not been comprehensively explored (see steps 2 , 3 , and 4 in figure 1). There is merely an intuitive and plausible explanation for the relationship - "the belief that individual employee performance has implications for firm-level outcomes has been prevalent among academics and practitioners for many years" $(24, \mathrm{p}$ 636). However, there is still a lack of theoretical foundation and generally accepted standards in theory, models, or business cases to link effective human resource management with individual and organizational performance and overall financial success.

Inspite of this scientific gap (ie, lack of validated models), organizations continue to require instruments to strategically align human resource and OSH interventions and outcomes with organizational objectives. Since investments in human resources should contribute to the organization's goals, individuals responsible for human resources and $\mathrm{OSH}$ activities require appropriate guidance and reporting structures. In production as well as in service industries, the focus is on cost reduction and value creation. Therefore investments of all kinds - including human-related ones - have to be justified and their contribution to strategic targets explained and understood in advance.

Table 1. Overview of theories in the field of connecting human resource/occupational safety and health (OSH) issues to organizational performance.

\begin{tabular}{ll}
\hline Theory approach & Content \\
\hline Resource-based view & $\begin{array}{l}\text { An organization achieves advantages compared to its direct competitors by developing specific resources (human resources } \\
\text { among them) which cannot easily be copied by other organizations. Underlying this theory is the hypothesis of the positive ef- } \\
\text { fects of human-related investments/interventions on the organization's performance. (17, 18) }\end{array}$ \\
$\begin{array}{l}\text { Strategic human } \\
\text { resource management }\end{array}$ & $\begin{array}{l}\text { Human resource measures have to be aligned with strategy and organizational values. Human resource and 0SH interventions } \\
\text { in different fields }(\text { eg, health, personal development) have to be coordinated in a holistic way to facilitate synergies between } \\
\text { them }(19,20,23)\end{array}$ \\
Signaling & $\begin{array}{l}\text { The signaling theory }(21,23) \text { is relevant in explaining corporate and human resource reputation. An organization's human } \\
\text { resource initiatives may attract potential applicants by serving as a signal of working conditions in the organization. }\end{array}$ \\
Social identity & $\begin{array}{l}\text { This theory }(21,22,23) \text { suggests that people classify themselves into social categories on the basis of various factors, such } \\
\text { as the organization for which they work, and that membership in these social categories influences an individual's self-concept } \\
\text { (21, 22). }\end{array}$ \\
\hline
\end{tabular}




\section{Method}

Researching and communicating evidence: the Balanced Scorecard

Set out in this paper, our method was to present a case study that shows the feasibility of applying the Balanced Scorecard approach to OSH in order to develop a business case which aligns human resources and organizational performance objectives. There are a limited number of business cases for OSH as the field is an emerging one, and yet the use of case studies offers multiple insights and the possibility to place a highly complex issue into context. This seems to be appropriate at a stage when theory building still needs elaboration. Conceptually applied in our case study, the constructive research approach $(25,26)$ is viewed as a very suitable methodology as it combines empirical research elements with a normatively intended research output offering concrete advice and recommendations. Our case study builds on the earlier work of other authors and their experiences with broad empirical as well as case study research on human capital, human resources, and OSH respectively $(4,5,7,9,27)$.

An important reason for choosing this approach was the communication dimension of the research method. The Balanced Scorecard is the most prominent example of an advanced performance measurement and reporting tool that enables the implementation and penetration of corporate strategies throughout the organization. It consists of strategic goals, key performance indicators, targets, and actions from four perspectives: (i) finance, (ii) customer (iii) process, and (iv) potential/learning $(28,29)$. Though the indicators focused on these four Balanced Scorecard layers picture the past and present rather than the future, the method includes a prospective focus because it gathers leading indicators for performance-relevant aspects. Moreover the Balanced Scorecard's further development emphasizes futurerelated goals.

The ideal process for developing a Balanced Scorecard begins with the setting of strategic goals resulting from the aforementioned four perspectives on a given strategy. For example, the strategy for an organisation's health department might be the reduction of absenteeism by improving the employees' health status, their motivation, and job satisfaction. At this point, a set of key performance indicators (see column "strategic measure" in figure 2) is defined for every strategic goal (see column "goal" in figure 2) allowing a comparison of planned and actual performance data (see figure 2, perspective "value added"). To reach the defined strategic goals, action programmes as well as budgets are allocated.

Kaplan \& Norton (28) have suggested to apply the four perspectives of (i) finance, (ii) customer, (iii) process, and (iv) potential/learning to the multi-dimensional performance measurement. More recently, they proposed to move away from the four-box model towards socalled "strategy maps" as visual representation of how intangible assets are converted into tangible outcomes $(29,4,5)$. Cause and effect relationships are a pivotal aspect of the strategy map concept, as well as performance measurement concepts in general (30). These relationships should provide a detailed and broad picture of

\begin{tabular}{|c|c|c|c|c|c|c|c|}
\hline Perspective & Strategy & Map & Goal & Strategic measure & Target & Action & Budget \\
\hline Value added & $\begin{array}{l}\text { Increas } \\
\text { Value ac }\end{array}$ & $\begin{array}{l}\text { e } \\
\text { ded }\end{array}$ & $\begin{array}{l}\text { Increase quality } \\
\text { Increase productivity } \\
\text { Decrease costs } \\
\text { Absenteeism }\end{array}$ & $\begin{array}{l}\text { Parts per million (ppm) } \\
\text { Productivity measure (number } \\
\text { of produced units) } \\
\text { Return on Investment (ROI) } \\
\text { of WHP measures } \\
\text { Attendance }\end{array}$ & $\begin{array}{l}-5 \% \\
+5 \% \\
+5 \% \\
+1 \%\end{array}$ & & \\
\hline \multirow{2}{*}{$\begin{array}{l}\text { Health \& } \\
\text { Behavior }\end{array}$} & $\begin{array}{c}\text { Psychological } \\
\text { stress }\end{array}$ & $\begin{array}{l}\text { Physical } \\
\text { stress }\end{array}$ & \multirow{2}{*}{$\begin{array}{l}\text { Avoid and minimise } \\
\text { psychological stress } \\
\text { Avoid and minimise } \\
\text { physical stress } \\
\text { Increase health awareness and } \\
\text { health behaviour } \\
\text { (executives and employees) }\end{array}$} & \multirow{2}{*}{$\begin{array}{l}\text { Number of work-related ailments } \\
\text { Number of work-related } \\
\text { psychological illnesses } \\
\text { Number of participants in WHP } \\
\text { events }\end{array}$} & \multirow{2}{*}{$\begin{array}{l}-5 \% \\
-5 \% \\
+5 \%\end{array}$} & \multirow[b]{2}{*}{$\begin{array}{l}\text { Marketing events for the } \\
\text { WHP actions }\end{array}$} & \multirow[b]{2}{*}{$€ x x x$} \\
\hline & \multicolumn{2}{|c|}{ Health behavior } & & & & & \\
\hline \multirow{2}{*}{$\begin{array}{l}\text { Workplace } \\
\text { Health Promotion } \\
\text { Processes }\end{array}$} & $\begin{array}{c}\text { Improve } \\
\text { ergonomics }\end{array}$ & $\begin{array}{c}\text { Improve } \\
\text { safety } \\
\text { at work }\end{array}$ & \multirow{2}{*}{$\begin{array}{l}\text { Improve ergonomics } \\
\text { Improve safety at work } \\
\text { Implement networking among } \\
\text { executieves }\end{array}$} & \multirow{2}{*}{$\begin{array}{l}\text { Number of ergonomic } \\
\text { workstations } \\
\text { Number of accidents } \\
\text { Process of networking } \\
\text { implemented }\end{array}$} & \multirow[t]{2}{*}{$\begin{array}{l}+5 \% \\
-5 \%\end{array}$} & \multirow{2}{*}{$\begin{array}{l}\text { Analysis of WHP actions } \\
\text { Analysis of WHP actions } \\
\text { Recommendation for the } \\
\text { formation of a networking } \\
\text { processes }\end{array}$} & \multirow{2}{*}{$\begin{array}{l}€ x x x \\
€ x x x \\
€ x x x\end{array}$} \\
\hline & \multicolumn{2}{|c|}{$\begin{array}{c}\begin{array}{c}\text { Implement networking } \\
\text { among executives }\end{array} \\
\end{array}$} & & & & & \\
\hline \multirow{2}{*}{\begin{tabular}{|l|} 
Workplace \\
Health Promotion \\
Potentials
\end{tabular}} & \multicolumn{2}{|c|}{$\begin{array}{l}\text { Development } \\
\text { of new topics }\end{array}$} & \multirow{2}{*}{$\begin{array}{l}\text { Development of new topics } \\
\text { Inplement customer focus } \\
\text { Increase competence for } \\
\text { prevention }\end{array}$} & \multirow{2}{*}{$\begin{array}{l}\text { Number of new topics } \\
\text { Index from employee questioning } \\
\begin{array}{l}\text { Number of trainings of employees } \\
\text { per annum }\end{array}\end{array}$} & \multirow{2}{*}{$\begin{array}{l}2 \text { per year } \\
3 \text { of } 5 \\
+5 \%\end{array}$} & \multirow{2}{*}{$\begin{array}{l}\text { Discussion of innovation } \\
\text { Culture guidelines } \\
\text { Well directed employee } \\
\text { demand and aid }\end{array}$} & \multirow{2}{*}{$\begin{array}{l}€ x x x \\
€ x x x \\
€ x x x\end{array}$} \\
\hline & $\begin{array}{l}\text { Implement } \\
\text { customer } \\
\text { focus }\end{array}$ & $\begin{array}{l}\text { Increase } \\
\text { competence } \\
\text { for } \\
\text { prevention }\end{array}$ & & & & & \\
\hline
\end{tabular}

Figure 2. Health Balanced Scorecard (4). (WHP = workplace health promotion) 
the reality. As a consequence, many dimensions such as time and linear and non-linear relationships have to be considered. Thus, strategy maps do not aim to integrate all possible cause and effect relationships, but only a few strategic relevant ones (29), depending on the defined (health) strategy. In this case study, the strategy map concept served as a logical framework for the development of a performance measurement tool enabling an economic evaluation of OSH programmes and their strategic control. Within the OSH context, the Balanced Scorecard is interpreted as an instrument focusing on internal relationships (see figure 2) in contrast to the "traditional" approach, which also incorporates external aspects (eg, the customer perspective).

In the proposed concept, employees are considered as internal customers, who have a self-interest in healthy and secure work. Following the logic of the Balanced Scorecard, we identified four perspectives for the multidimensional performance measurement of OSH: (i) performance/value added: which OSH cost and benefit goals have to be defined to support the economic goals of the firm? (ii) internal stakeholder (health and behaviour of employees/customers): what strategic goals concerning the employee's health behavior have to be defined to contribute to the performance goals? (iii) workplace health promotion processes: how do $\mathrm{OSH}$ processes have to be designed to contribute to the desired health behavior of employees as well as organizational performance? (iv) workplace health promotion potential: how do the OSH actors' potentials and capabilities have to be advanced in order to reach the performance, stakeholder, and process goals?

\section{Development of the case study}

The proposed conceptual framework was developed and implemented as a case study at a production centre of a multinational automotive industry firm in Germany, employing about 3500 people. In order to map the strategic health objectives, we conducted a strategy workshop as well as 31 semi-structured interviews with managers (senior managers, team leaders, and foremen) and members of the medical department (medical doctors, social consultants, human resources/OSH staff). The according results led to the development of an individual corporate health strategy map. In a scientific sense, the strategy map represents a variety of constructs and a set of cause and effect chains.

In order to measure the relevant health issues and especially the success of the proposed cause and effect chains in the strategy map, each strategic goal was carefully operationalized via specific measures. Based on an extensive literature review and the above-mentioned workshops and interviews, we developed a comprehensive questionnaire, then discussed and revised it with the involvement of various departments. Health-related data were collected for all the formulated constructs via a written questionnaire. The sample contained 428 bluecollar male workers. The questionnaire considered 145 items (qualitative data) including information on demographics, work satisfaction, health and wellbeing, satisfaction with health interventions, leadership and corporate performance. The questionnaire included mainly closed questions and featured a five-point answer scale. Quantitative data (value added perspective, see figure 2) for the 21 researched cost centres were obtained from different internal information systems (eg, accounting, human resources, quality department).

\section{Results}

One major concern of the case study at hand was how to analyze the impact of health (workplace health promotion processes, and health and behavior items in figure 2) on performance-related aspects such as quality, productivity, cost reduction and absenteeism. As pointed out in the theory section, there is currently an insufficient understanding as to how these relate. In the course of the case study, we obtained many results with respect to correlations within - and between - the different strategy map levels. In this article, however, our aim was to concentrate on the performance-related impacts in order to answer the question: "Do interventions focused on the promotion of workplace health support corporate financial objectives and, if so, which health-related aspects are the most important?"

In order to conceptualize a method by which qualitative factors such as human resources and OSH aspects contribute to organizational performance or the valueadded layer, we undertook multivariate regression analyses of the indicators at the different levels. In this paper, we only present the regression models of the performance level. The independent variables (eg, workplace health promotion processes, and health and behavior items in figure 2) were gathered from the questionnaire described above, the dependent variables were taken from the financial controlling system. Our analysis was challenged by problems related to data availability/ completeness, reliability, and validity as different organizational entities and various information technology systems had neither the same data definition nor format. Especially management accounting, the human resources department, and the medical area approached comparable issues in very different ways. The performance data were gathered from the organization's financial control system and were standardized for comparability where necessary. Therefore, quotients of negative deviations and target values were used (see table 2). 
The results supported a correlation of health-related issues and organizational performance. Adverse organizational or situational work conditions had negative performance impacts, whereas measures to prevent or treat ill health or improve job satisfaction/motivation had positive performance effects (see table 3 ). The influence of leadership on performance seemed to be substantial but negative, which was unexpected. Eventually this is grounded in the complex structure of leadership (eg, staff/task-related, expertise/experienced-based) that was only partially incorporated in

Table 2. Performance data from management accounting.

\begin{tabular}{ll}
\hline $\begin{array}{l}\text { Performance } \\
\text { aspect }\end{array}$ & Indicator \\
\hline Absenteeism ${ }^{\text {a }}$ & Average per cost centre \\
Productivity & $\begin{array}{l}\text { Productivity figure: negative deviation from target } \\
\text { productivity (ie, a low figure stands for high } \\
\text { productivity) }\end{array}$ \\
& $\begin{array}{l}\text { Asset efficiency: negative deviation from target (ie, a } \\
\text { low figure stands for high productivity) }\end{array}$ \\
& $\begin{array}{l}\text { Defective product rate: negative deviation from } \\
\text { estimated defect product rate (ie, high figure stands for } \\
\text { low defect rates and therefore high quality) }\end{array}$ \\
& $\begin{array}{l}\text { Rework: absolute figures per cost centre } \\
\text { Cost savings }\end{array}$ \\
\hline
\end{tabular}

${ }^{a}$ Absent days.

Table 3. Results of multivariate regression analyses. $\left(R^{2}=\right.$ determination coefficient ${ }^{\mathrm{a}}$, $\beta$ = beta coefficient)

\begin{tabular}{lllr}
\hline Dependent variable & Independent variable & $\mathrm{R}^{2}$ & $\beta^{\mathrm{b}}$ \\
\hline Absenteeism & Scope of action & 0.13 & -0.27 \\
& Fear of job loss & & -0.21 \\
& Bad health & 0.21 \\
Productivity-figure & Leadership & 0.14 & 0.32 \\
& Demand of task (lifting, & & \\
& carrying heavy weights, & & 0.23 \\
& one-sided movements, etc) & & -0.18 \\
Asset efficiency & Claim of medical services & & 0.25 \\
Defect product rate & Leadership & 0.05 & -0.38 \\
& Leadership & 0.21 & \\
& Demands of work situation & & -0.21 \\
(noise, dirt, heat, etc) & & -0.19 \\
Rework & Fear of job loss & -0.32 \\
Cost savings & Social support & 0.09 & -0.16 \\
& Bad health & & -0.48 \\
& Leadership & 0.18 & \\
& Acceptance of important & & \\
& organizational decisions & & 0.30 \\
\hline
\end{tabular}

a For example, $\mathrm{R}^{2}=0.50$, means $50 \%$ variance explanation of dependent variable)

${ }^{b}$ Only significant results $(\mathrm{P} \leq 0.05)$ are considered. the questionnaire and further in the analysis. Due to the study's health focus and the organization's demand to restrict the number of items, the leadership items only contained health-impacting aspects such as trust, appreciation, career advancement, support, and handling of conflicts. Basically leadership involves staff- and taskrelated aspects $(31,32)$. Thus different working situations require different levels of staff- and task-related leadership behavior.

Further research, especially concerning the impact of leadership's performance, is necessary. The findings from the questionnaire are, however, not this study's main result. The major outcome of the project was rather the concept itself, its implementation process, and - within this - its suitability for building a bridge between staff- and health-related issues and key performance factors in a transparent and reportable way. The statistical analyses were rather a means to demonstrate the applicability of a transparent model to, and its effect on, the strategic management of OSH issues.

Due to the lack of data and access to the management accounting system, the explained variance of the regression models as well as the number of significant regressions were lower than expected. The problem of missing health-related data, data quality, and availability is a major limitation of studies on the linkage between human resources or health and business performance (33).

\section{Discussion}

The proof of associations between OSH and overall organizational performance by statistical methods is not trivial. Therefore, it cannot be a surprise that there is still only a limited theoretical understanding of $\mathrm{OSH}$ business cases.

The optimum use of OSH in organizations is a complex issue and iterative, self-enhancing processes may play a role along side linear causal relationships. However, our results showed that adverse working conditions had negative performance impacts while OSH interventions showed positive effects, as suggested in the causal chain assumptions of figure 1 . So basically the approach proved to be a feasible means of building the bridge between health- and organizational performance-related issues. The acceptance of the instrument within the case study organization was therefore high.

Nevertheless, effective OSH management requires improved availability and quality of data in order to prove the assumed relationships between OSH and organizational performance (see figure 1). The data accessed for our study scarcely featured human resource or health issues. Information concerning cost centre-related fluctuation, employee turnover costs, individual-related data 
in terms of effectiveness or efficiency of special medical treatments or prevention measures, and cost-efficiency information of medical services, among others, was either not available or not provided due to data privacy protection requirements. The answer to this problem presupposes the enhancement of management accounting systems with OSH-related data - this is a major concern of future research.

The definition and measurement of eligible indicators on all Balanced Scorecard levels requires a lot of effort, time, and commitment, the latter especially from management. The Balanced Scorecard is a framework model, which has to be diligently adapted to the specific character of each company. This procedure presumes a human resources strategy that is aligned with - or rather embedded in - the enterprise's general competitive strategy.

Moreover, the knowledge and experience of different scientific disciplines have to be combined in order to improve and establish human resource and healthrelated management accounting and reporting systems. In this process, certain aspects have to be developed by business research, whereas the diligent analyses of OSH aspects must be done by those in the social sciences, such as work psychology or occupational health. Hence, the elaboration of a theoretical background has to be interdisciplinary $(4,5,7)$.

The objective of this article was to show how human resources/OSH may be linked to the business performance of the case study organization (in this case an automobile manufacturer). Grounded in the performance measurement and management literature, the Balanced Scorecard/strategy map concept seems to be a promising approach for bridging theory-based needs with the practical claims of different stakeholder groups. The concept has a built-in flexibility in order to be adaptable to different users and yet constitutes a performance measurement tool comprising all the formal elements to potentially satisfy the demand of theory-based causal chains for the proof of successful interventions (ie, theoretical rigor).

The case study showed that this approach is feasible - but also made some serious research challenges evident: the proposed causal chains are very generic ones. In reality, they were more specific but seemed to be of an anecdotal evidence sort. More research is needed in order to develop (and cluster) appropriate goals and measures for OSH in the whole chain of potential/process/customer/success (eg, by means of an "indicator catalogue"). A first attempt is made within this case study and the underlying research project (5). This goes hand in hand with the increasing need for harmonized datasets for a business case of OSH.

\section{Acknowledgements}

Above all we thank Dr Jos Verbeek (the Finnish Institute of Occupational Health) for his support and valuable advice at all stages of the project. Furthermore, we thank Regina Passoth (graduate translator) for the grammatical and stylistic review. The research leading to these results has received funding from the European Community's Seventh Framework Programme (FP7/2007-2013) under grant agreement number $200549 \mathrm{EcOSH}$

\section{References}

1. Zivnuska S, Ketchen DJ, Snow CC. Implications of the converging economy for human resource management. In: Schuler RS, Jackson SE. Strategic human resource management. 2nd ed. Malden, Oxford, Carlton: Blackwell Publishing; 2007. p 49-75.

2. Becker BE, Huselid MA, Pickus PS, Spratt MF. Human resources as a source of shareholder value: research and recommendations. Hum Resour Manage J. 1997;36:39-47.

3. Nielsen C, Hussi T, Schunder-Tatzber S, Roslander R, Ahonen $\mathrm{G}$. The interrelations between health and intellectual capital. In: Johanson U, Ahonen G, Roslender R, editors. Work health and management control. Stockholm: Thomson Fakta; 2007. p 241-68.

4. Möller K, Gamm N, Braun M, Iserloh B, Kastner M, Kliesch G, et al. Strategische Steuerung der betrieblichen Gesundheitsförderung mit Strategy Maps [Strategic management and control of workplace health promotion by means of strategy maps]. Zeitschrift für Management. 2008;3:247-80.

5. Köper B. Strategieorientierte Steuerung von betrieblicher Gesundheitsförderung am Beispiel eines Balanced-Scorecardbasierten Ansatzes [Strategy-orientated controlling of workplace health promotion by means of a Balanced Scorecard approach]. In: Gesellschaft für Arbeitswissenschaft, editor. Arbeit, Beschäftigungsfähigkeit und Produktivität im 21. Jahrhundert. [Work, employability and productivity in the $21 \mathrm{st}$ century]; 2009. p 317-2.

6. Verbeek J, Pulliainen M, Kankaanpää E. A systematic review of occupational safety and health business cases. Scand J Work Environ Health. 2009;35(6):403-412.

7. Pennig S, Kremeskötter T, Nolle A, Maziul M, Vogt J. Ökonomische Evaluation von Personalressourcen und Personalarbeit [Economic evaluation of human resources and personnel work / -development]. Bremerhaven (Germany): NW-Verlag; 2006.

8. Becker GS. Investment in human capital: a theoretical analysis. J Polit Econ. 1962;70:573-94.

9. Glaser J, Hornung S, Labes M. Indikatoren für die Humanressourcenförderung - Humancapital messen, fördern und wertschöpfend einsetzen [Indicators for the promotion of 
human resources - measuring, promoting and utilizing human capital for value creation]. Bremerhaven (Germany): NWVerlag; 2007.

10. Hacker W. Allgemeine Arbeitspsychologie - Psychische Regulationen von Arbeitstätigkeiten [General work psychology - psychological regulations of work]. Bern: Huber; 1998.

11. World Health Organisation (WHO). Constitution of the WHO. 45th edition supplement [Internet]. Geneva: WHO; 2006 [cited: 21 September 2009]. Available from: www.who. int/governance/eb/constitution/eu/index.htm

12. Frischenschlager O. Vom Krankheits- zum Gesundheitsbegriff [To alter the perspective from disease to health]. In: Hutterer-Kirsch R, Pfersmann V, Farag IS, editors. Psychotherapie, Lebensqualität und Prophylaxe: Beiträge zur Gesundheitsvorsorge in Gesellschaftspolitik, Arbeitswelt und beim Individuum [In: Psychotherapy, life quality and prophylaxis: contributions for health care in social policy, working world and for individuals]. Wien: Springer; 1996. p 3-16.

13. Gairing F. Organisationsentwicklung als Lernprozess von Menschen und Systemen [Organizational Development as learning process of humans and systems]. Weinheim (Germany): Deutscher Studien Verlag; 1999.

14. Ahonen G, Hussi T. Workability and human resource reporting - the Finnish experience. In: Johansson U, Ahonen $\mathrm{G}$, Roslender R, editors. Work health and management control. Stockholm: Thomson Fakta; 2007. p 269-88.

15. Almqvist R, Backlund A, Sjöblom A, Rimmel G. Management control of health - the Swedish example. In: Johansson U, Ahonen G, Roslender R, editors. Work health and management control. Stockholm: Thomson Fakta; 2007. p 291-316.

16. Rimmel G, Nielsen C. Health disclosures in capital market communication. In: Johansson U, Ahonen G, Roslender R, editors. Work health and management control. Stockholm: Thomson Fakta; 2007. p 319-33.

17. Penrose ET. The theory of the growth of the firm. Oxford (NY): Oxford University Press; 1959.

18. Barney J. Firm resources and sustained competitive advantage. J Manage. 1991;17(1):99-120.

19. Evans P, Pucik V, Barsoux J. The global challenge: frameworks for international human resource management. New York (NY): McGraw-Hill Irwin; 2002.

20. Delery J, Doty H. Models of theorizing in strategic human resource management: tests of universalistic, contingency and configurational performance predictions. Acad Manage J. 1996;39:802-35.
21. Turban DB, Greening DW. Corporate social performance and organizational attractiveness to prospective employees. Acad Manage J. 1997;40(3):658-62.

22. Ashforth BE, Mail F. Social identity theory and the organization. Acad Manage J. 1989;14(1):20-39.

23. Joo BK, McLean G. Best employer studies: a conceptual model from a literature review and a case study. Hum Resour Dev Rev. 2006;5(2):228-57.

24. Huselid, M. The impact of human resource management practices on turnover, productivity and corporate financial performance. Acad Manage J. 1995;38:972-991.

25. Kasanen E, Lukka K, Siitonen A. The constructive research approach in management accounting research. J Manage Account Res. 1993;5:243-64.

26. Labro E, Tuomela T-S. On bringing more action into management accounting research: process considerations based on two constructive case studies. Eur Account Rev. 2003;12 (3):409-42.

27. Zwetsloot GIJM, van Scheppingen AR. Towards a strategic business case for health management. In: Johansson U, Ahonen G, Roslender R, editors. Work health and management control. Stockholm: Thomson Fakta; 2007. p 183-213.

28. Kaplan RS, Norton DP. The balanced scorecard. Boston (MA): Harvard Business School Press; 1996.

29. Kaplan RS, Norton DP. Strategy maps: converting intangible assets into tangible outcomes. Boston (MA): Harvard Business School Publishing Corporation; 2004.

30. Ittner C, Larcker DF. Assessing empirical research in managerial accounting: a value-based management perspective. J Account Econ. 2001;32(1-3):349-410.

31. Fiedler FE. Führungstheorien - Kontingenztheorie [Leadership theories - contingency theory]. In: Kieser A, Rebs G Wunderer R, editors. Handwörterbuch der Führung; 1987. p 809-23.

32. Von Rosenstiel L. Kommunikation und Führung in Arbeitsgruppen [Communication and leadership in working teams].In: SchulerH, editor.Lehrbuch Organisationspsychologie [Textbook organisational psychology]. Bern: Huber; 1995. p 321-51.

33. Badura B, Greiner W, Rixgens $P$, Ueberle M, Behr M. Social Capital. Sozialkapital - Grundlagen von Gesundheit und Sicherheit [Basic principles of health and performance]. Heidelberg (Germany): Springer; 2008.

Received for publication: 17 July 2009 